\title{
ANALISIS TRANFER PRICING DALAM LENDING ACTIVITIES BANKING DENGAN MENGGUNAKAN ARM'S LENGTH PRINCIPLE
}

Deni Danial Kesa ${ }^{1}$

Erwin Harinurdin ${ }^{2}$

Asti Setiawati ${ }^{3}$

1,2 Laboratorium Keuangan dan Perbankan, Program Vokasi UI, denidanialkesa@gmail.com, ewink_h@yahoo.com, asti.setiawati@yahoo.co.id

Diterima : 7 Mei 2015

Layak Terbit : 29 Mei 2015

\begin{abstract}
Abstrak
Regulatory motivation sering dilakukan oleh beberapa industri yang terkait dengan peraturan pengawasan yang ketat seperti bank dan asuransi. Hal ini terkait dengan salah satunya dalam pemenuhan Capital Adequacy Ratio (CAR) dan Solvency Margin ratio yang dapat menciptakan insentif bagi manajemen untuk melakukan earnings management demi kepentingan pihak regulator. Dari penelitian terdahulu ditemukan adanya indikasi bahwa manajemen bank melakukan praktik earnings management dalam rangka pemenuhan terhadap peraturan (regulator) dan investor.

Salah satu kebijakan API adalah tentang kepemilikan tunggal pada perbankan Indonesia (Single Presence Policy). Karena kebijakan tersebut akan memiliki konsekuensi yang dapat mempengaruhi keberadaan bank-bank di Indonesia dan jasa perbankan. Untuk itu perlu dilakukan penelitian terhadap transaksi perbankan terhadap pihak - pihak terafiliasi dalam penggunaan prinsip kewajaran dan kelaziman usaha (arm's length principle). Metode penelitian yang digunakan dalam penelitian ini adalah deskriptif analisis dan hasil penelitian akan dianalisis secara kualitatif.
\end{abstract}

Kata kunci : Prinsip kewajaran dan kelaziman usaha, metode perbandingan harga, perbankan.

\section{Abstract}

Regulatory motivation is often done by some of the industries associated with strict regulatory supervision, such as banks and insurers. It is associated with one of them in fulfillment of the Capital Adequacy Ratio (CAR) and Solvency Margin ratio which can create incentives for management to make earnings management in the interest of regulators. From previous studies found indications that the bank's management to practice earnings management in order to meet regulatory (regulator) and the investor.

API is one of the policy on sole ownership in Indonesian banks (Single Presence Policy). Because these policies will have consequences that could affect the existence of banks in Indonesia and banking services. It is necessary for research on banking transactions of the party - affiliated parties in the use of the principles of fairness and the predominance of business (arm's length principle). The method used in this research is descriptive analysis and the results will be analyzed qualitatively. Keywords: Principles of fairness and the predominance of business, price comparison method, banking.

\section{PENDAHULUAN}

\section{Latar Belakang}

Kedatangan milenium baru sebagai wajah dunia baru di dunia usaha tidak disambut dengan yang ramah. Salah satunya adalah terkuaknya status skandal Enron, Worldcom, Ahold dan Tyco. Berbagai pendapapat muncul seputar pemicunya skandal salah satunya earnings management. Secara umum, penelitian mengenai earnings management berdasarkan hasil penelitian yang dilakukan 
oleh Scott, (1997), Healy dan Wahlen (1999), Defond and Jiambalvo (1994), Betty et all (2002) Wyatt (2004), Cheng dan Warfield (2005) menunjukkan bahwa tindakan manajemen didorong oleh motivasi berikut ini: bonus scheme motivations (bonus hypothesis), debt covenan hypothesis, political atau size hypothesis, perpajakan (taxation), pergantian manajemen (CEO), regulatory motivations.

Motivasi yang terakhir yaitu regulatory motivation sering dilakukan oleh beberapa industri yang terkait dengan peraturan pengawasan yang ketat seperti bank dan asuransi terkait dalam pemenuhan Capital Adequacy Ratio (CAR) dan Solvency Margin ratio dapat menciptakan insentif bagi manajemen untuk melakukan earnings management demi kepentingan pihak regulator. Penelitian dari Beaver dan Engel; Ahmed, Takeda dan Shawn serta betty dan Petrony ditemukan adanya indikasi bahwa manajemen bank melakukan praktek earnings management dalam rangka pemenuhan terhadap peraturan (regulator) dan investor.

$$
\text { Berdasarkan penelitian-penelitian }
$$

yang telah dilakukan tersebut, terbukti bahwa manajemen melakukan earnings management karena adanya motivasi yang lebih bersifat oppotunistic dibandingkan dengan alasan efficiency. Pada dasarnya rewards oleh manajemen dengan melakukan tindakan earnings management adalah harga saham perusahaan yang semakin, biaya modal yang lebih rendah, manajemen insentif yang tinggi dan biaya politis yang rendah (C Mulford and E Commiskey; 2002 dalam Sensi 2007) . Era globalisasi ekonomi yang berkembang seiring dengan pertumbuhan teknologi informasi dan komunikasi telah menjadikan definisi dan cakupan interaksi antar negara menjadi semakin luas dan seolah tanpa batas.

Dalam isu transfer pricing permasalahan timbul sehubungan dengan adanya istilah abuse of transfer pricing. Instilah abuse of transfer pricing melekat atas transkasi yang antar perusahaan yang saling berafiliasi. Istilah ini mendefinisikan transfer pricing dari sudut pandang negatif, yaitu sebagai bentuk atau upaya penyelahgunaan mekanisme transfer pricing demi tujuan penghindaran pajak melalui upaya pengalihan keuntungan (profit shifting) dari negara yang memiliki tarif pajak tinggi ke negara yang memiliki tarif pajak lebih rendah. Dengan kata lain abuse tranfer pricing adalah pengalihan atas penghasilan kena pajak (taxable income) dari suatu perusahaan yang dimiliki oleh perusahaan multinasional ke negara-negara yang tarifpajaknya rendah dalam rangka mengurangi total beban pajak dari grup perusahaan multinasional tersebut.

\section{METODE}

Dalam sebuah penelitian ilmiah langkah awal yang paling umum dilakukan adalah menetukan pendekatan dan jenis penelitian yang akan dilakukan. Pemilihan jenis atau metode penelitian apa yang digunakan tergantung pada masalah penelitian yang akan telah ditentukan. Metode penelitian pada dasarnya merupakan cara ilmiah untuk mendapatkan data dengan tujuan dan kegunaan tertentu. 
3.1. Pendekatan Penelitian.

Untuk mengetahui bagaimana proses dan kesesuaian pemenuhan prinsip kewajaran dan kelaziman usaha (arm's length principle) atas transkasi pinjaman (loan) oleh lembaga keuangan (Perbankan) kepada perusahaan yang berafiliasi sesuai dengan butir-butir rumusan masalah dan tujuan penelitian, maka digunakan pendekatan penelitian menggunakan metode penelitian kualitatif, karena dengan metode ini data yang didapat akan lebih lengkap, lebih mendalam, kredibel, dan bermakna sehingga tujuan penelitian dapat tercapai. Menurut Irawan dalam peneltian kualitatif, metodologi yang digunakan memiliki ciri yang unik. Ciri tersebut bermula dari permasalahan penelitian yang dimulai dari pertanyaan luas dan umum, pengumpulan data yang fleksibel, terbuka dan kualitatif, serta penyimpulan temuan yang bersifat induktif dan tidak digeneralisasikan.

\section{.HASIL DAN PEMBAHASAN}

Peraturan perpajakan domestik Indonesia mengatur mengenai kewajiban penerapan arm's length principle dalam transaksi diantara pihak yang berafiliasi beserta peraturan lainnya yang berkaitan dengan hubungan istimewa. Berikut adalah dasar hukum mengenai penerapan arm's length principle dan hubungan istimewa di Indonesia:

1. Undang - Undang Nomor 36 Tahun 2008 Tentang Perubahan Keempat Atas Undang - Undang Nomor 7 Tahun 1983

Tentang Pajak Penghasilan
2. Peraturan Direktur Jenderal Pajak Nomor: Per-32/PJ/2011 Tentang

Perubahan Atas Peraturan Direktur Jenderal Pajak Nomor Per-43/PJ/2010 Tentang Penerapan Prinsip Kewajaran dan Kelaziman Usaha Dalam Transaksi Antara Wajib Pajak Dengan Pihak yang Mempunyai Hubungan Istimewa

3. Peraturan Direktur Jenderal Pajak Nomor Per-34/PJ/2010 Tentang Bentuk Formulir Surat Pemberitahuan Tahunan Pajak Penghasilan Wajib Pajak Orang Pribadi dan Wajib Pajak Badan Beserta Petunjuk Pengisiannya

4. Keputusan Direktur Jenderal Pajak Nomor: KEP-01/PJ.7/1993 Tentang Pedoman Pemeriksaan Pajak Terhadap Wajib Pajak yang Mempunyai Hubungan Istimewa

5. Surat Direktur Pemeriksaan dan Penagihan Nomor S-153/PJ.04/2010 Tentang Panduan Pemeriksaan Kewajaran Transaksi Afiliasi

6. Peraturan Direktur Jenderal Pajak Nomor: Per-69/PJ/2010 Tentang Kesepakatan Harga Transfer (Advance Pricing Agreement)

7. Peraturan Direktur Jenderal Pajak Nomor: Per-48/PJ/2010 Tentang Tata Cara Pelaksanaan Prosedur Persetujuan Bersama (Mutual Agreement Procedure) Berdasarkan Persetujuan Penghindaran Pajak Berganda

Selain Peraturan tersebut di atas, dalam menangani transaksi hubungan istimewa dan penerapan arm's length principle, Indonesia juga menggunakan beberapa sumber hukum 
lain yang diakui secara internasional. Sumber hukum tersebut adalah:

\section{OECD Transfer Pricing Guidelines:} merupakan pedoman terhadap transaksi hubungan istimewa dan kaitannya dengan transfer pricing yang disusun oleh OECD, sebuah organisasi kerjasama ekonomi yang beranggotakan 30 negara maju di dunia.

2. United Nation Transfer Pricing Manual (UN TP Manual): Merupakan pedoman terhadap transaksi hubungan istimewa dan kaitannya dengan transfer pricing yang disusun oleh United Nations khusus bagi negara-negara berkembang (developing countries).

3. OECD Model Tax Convention On Income and Capital: Merupakan pedoman mengenai transaksi dan isu perpajakan internasional yang disusun oleh OECD, sebuah organisasi kerjasama ekonomi yang beranggotakan 30 negara maju di dunia, demi menghindari munculnya isu perpajakan berganda yang timbul dari adanya transaksi perpajakan internasional tersebut.

Adanya transaksi ekonomi yang berkaitan dengan transfer pricing dan dilakukan oleh pihak-pihak yang memiliki hubungan istimewa (berafiliasi), merupakan latar belakang utama dari munculnya kewajiban penerapan prinsip kewajaran dan kelaziman usaha atau arm's length principle terhadap transaksi yang bersangkutan. Transaksi yang terjadi diantara pihak yang memiliki hubungan istimewa sering kali tidak sebanding atau tidak menunjukkan hasil yang sama bila dibandingkan dengan transaksi sejenis yang dilakukan oleh pihak independen. Pada saat ini muncul istilah abuse of transfer pricing, yaitu suatu bentuk penghindaran pajak secara ilegal melalui penyalahgunaan mekanisme transfer pricing.

Pada dasarnya, pernyataan mengenai arm's length principle pertama kali diperkenalkan oleh organisasi kerjasama ekonomi antara negara-negara maju yaitu OECD (Organization for Economic Cooperation and Development) di dalam paragraf 1 artikel 9 OECD Model Tax Convention yang selanjutnya dibahas secara lebih mendalam oleh OECD pada bab 1 OECD Transfer Pricing Guidelines (OECD TP Guidelines). Di dalam artikel tersebut, arm's length principle dijelaskan sebagai berikut: (when) conditions are made or imposed between the two (associated) enterprises in their commercial or financial relations which differ from those which would be made between independent enterprises, then any profits which would, but for those conditions, have accrued to one of the enterprises, but, by reason of those conditions, have not so accrued, may be included in the profits of that enterprise and taxed accordingly.

Peraturan perpajakan domestik Indonesia pun telah mengatur mengenai kewajiban menerapkan arm's length principle dalam transaksi yang dilakukan oleh pihak-pihak yang memiliki hubungan istimewa. Kewajiban tersebut tertera dalam Peraturan Direktur Jenderal Pajak Nomor Per-32/PJ/2011 Tentang Penerapan Prinsip Kewajaran dan Kelaziman Usaha Dalam Transaksi Antar wajib pajak. 


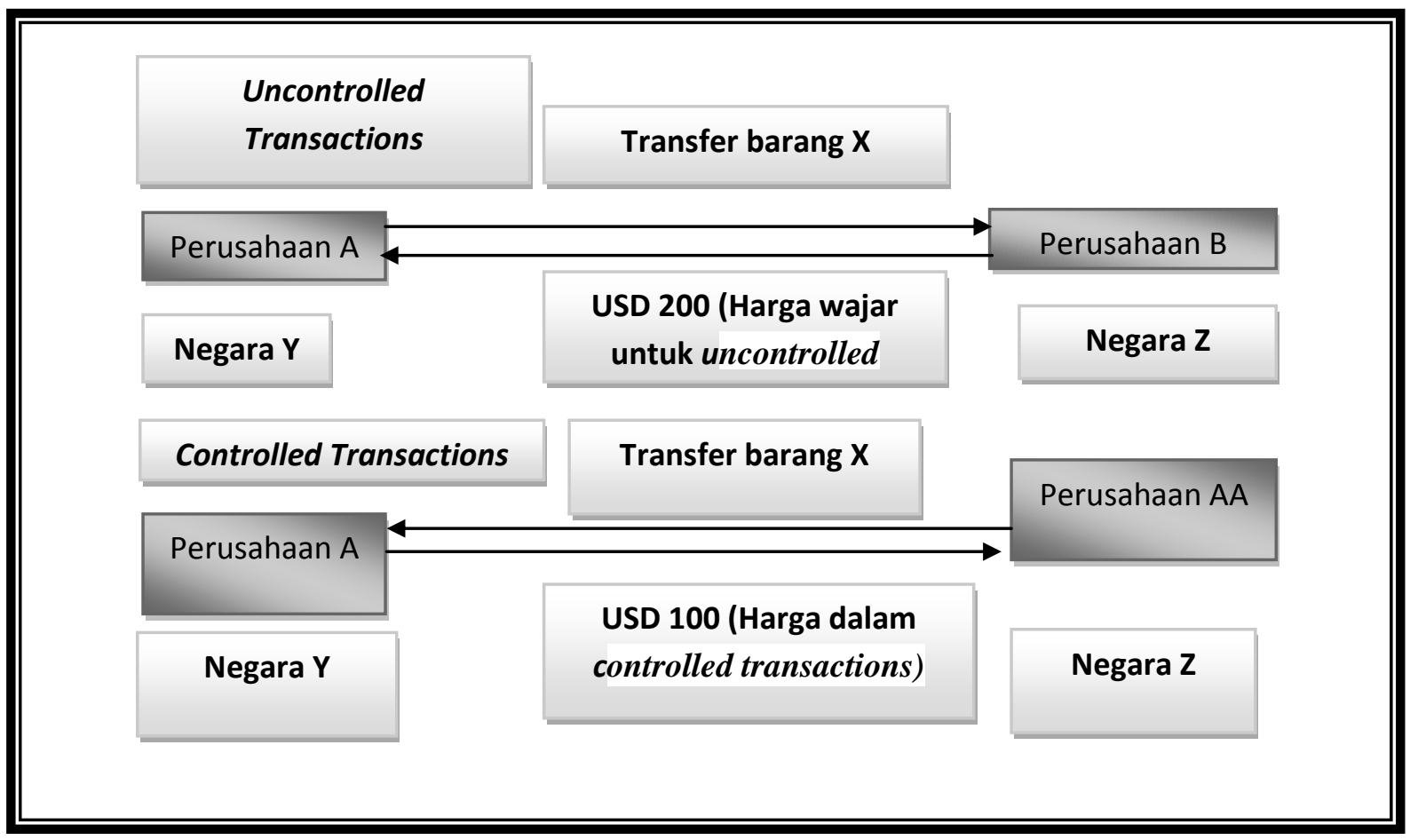

Gambar 1

Controlled Transactions dan Uncontrolled Transactions

Sumber: Gareth Green, Transfer Pricing Manual, UK: BNA International Inc, 2008, hlm 12. Diolah kembali oleh penulis.

Dalam peraturan tersebut diatur bahwa wajib pajak yang melakukan transaksi dengan pihak-pihak yang memiliki hubungan yang merupakan wajib pajak dalam negeri atau bentuk usaha tetap di Indonesia wajib menerapkan prinsip kewajaran dan kelaziman usaha. Lebih lanjut dijelaskan dalam ayat 3, prinsip kewajaran dan kelaziman usaha mendasarkan pada norma bahwa harga atau laba transaksi yang dilakukan oleh pihak pihak yang tidak memiliki hubungan istimewa ditentukan oleh kekuatan pasar, sehingga transaksi tersebut mencerminkan harga pasar yang wajar (fair market value). Sejalan dengan konsep arm's length principle yang dinyatakan dalam OECD TP Guidelines.
Pasal 1 Ayat 5 Peraturan Direktur Jenderal Pajak Nomor Per-32/PJ/2011 Tentang Penerapan Prinsip Kewajaran dan Kelaziman Usaha Dalam Transaksi Antara Wajib Pajak Dengan Pihak yang Mempunyai Hubungan Istimewa. Menjelasakan konsep arm's length principle sebagai prinsip yang mengatur bahwa apabila kondisi dalam transaksi yang dilakukan antara pihak yang mempunyai hubungan istimewa sama atau sebanding dengan kondisi dalam transaksi yang dilakukan antara pihak yang tidak mempunyai hubungan istimewa yang menjadi pembanding, maka harga atau laba dalam transaksi yang dilakukan antara pihak-pihak yang mempunyai hubungan istimewa harus 
sama dengan atau berada dalam rentang harga atau laba dalam transaksi yang dilakukan antara pihak yang tidak mempunyai hubungan istimewa yang menjadi pembanding.

Berkaitan dengan pemenuhan prinsip kewajaran dan kelaziman usaha, perbedaan ini harus dianalisa secara lebih lanjut untuk memahami faktor yang menimbulkan terjadinya perbedaan sehingga transaksi yang terjadi antar pihak yang memiliki hubungan istimewa (perusahaan A dengan perusahaan AA) menunjukkan hasil yang tidak sebanding (tidak arm's length) dengan transaksi yang bersifat independen (perusahaan A dengan perusahaan B).

Berdasarkan latar belakang kewajiban pemenuhan arm's length principle tersebut di atas, maka pemahaman terhadap konsep hubungan istimewa sangatlah vital. Hal ini disebabkan karena munculnya kewajiban pemenuhan arm's length principle tersebut di latar belakangi oleh adanya transaksi ekonomi atau transaksi transfer harga (transfer pricing) yang terjadi diantara pihak yang memiliki hubungan istimewa.

OECD dalam artikel 9 OECD Model Tax Convention telah mendefinisikan konsep hubungan istimewa atau yang kerap kali disebut sebagai associated enterprise. Dalam artikel tersebut OECD mendefinisikan konsep associated enterprise sebagai berikut: Where: (a) An enterprise of a Contracting State participates directly or indirectly in the management, control or capital of an enterprise of the other Contracting State, or (b) The same persons participate directly or indirectly in the management, control or capital of an enterprise of a Contracting State and an enterprise of the other Contracting State.

Di Indonesia, pendefinisian konsep hubungan istimewa terdapat dalam UndangUndang Pajak Penghasilan Nomor 36 Tahun 2008 Pasal 18 Ayat 4. Dalam pasal tersebut, kategori pihak yang memiliki hubungan istimewa adalah:

1. Wajib pajak mempunyai penyertaan modal langsung atau tidak langsung paling rendah $25 \%$ (dua puluh lima persen) pada Wajib Pajak lain; hubungan antara wajib pajak dengan penyertaan paling rendah $25 \%$ (dua puluh lima persen) pada dua wajib pajak atau lebih; atau hubungan di antara dua wajib pajak atau lebih yang disebut terakhir;

2. Wajib pajak menguasai wajib pajak lainnya atau dua atau lebih wajib pajak berada di bawah penguasaan yang sama baik langsung maupun tidak langsung atau

3. Terdapat hubungan keluarga baik sedarah maupun semenda dalam garis keturunan lurus dan/atau ke samping satu derajat.

Lebih lanjut di dalam Penjelasan Pasal 18 ayat 4 tersebut dijelaskan mengenai ketiga konsep hubungan istimewa tersebut. Dalam Penjelasan Pasal 18 ayat 4 Huruf a UndangUndang Pajak Penghasilan Nomor 36 Tahun 2008, dijelaskan mengenai contoh dari definisi hubungan istimewa atas dasar penyertaan modal tersebut diatas, yaitu: (i) apabila PT A mempunyai $50 \%$ (lima puluh persen) saham PT B. Pemilikan saham oleh PT A merupakan penyertaan langsung; (ii) Selanjutnya, apabila PT B mempunyai 50\% (lima puluh persen) 
saham PT C, PT A sebagai pemegang saham PT B secara tidak langsung mempunyai penyertaan pada PT C sebesar 25\% (dua puluh lima persen). Dalam hal demikian, antara PT A, PT B, dan PT C dianggap terdapat hubungan istimewa; (iii) Apabila PT A juga memiliki 25\% (dua puluh lima persen) saham PT D, antara PT B, PT C, dan PT D dianggap terdapat hubungan istimewa. di bawah penguasaan yang sama. Demikian juga hubungan di antara beberapa perusahaan yang berada dalam penguasaan yang sama tersebut.

Selanjutnya dalam Penjelasan Pasal 18 ayat 4 Huruf b, dijelaskan mengenai konsep hubungan istimewa yang diakibatkan karena hubungan keluarga.

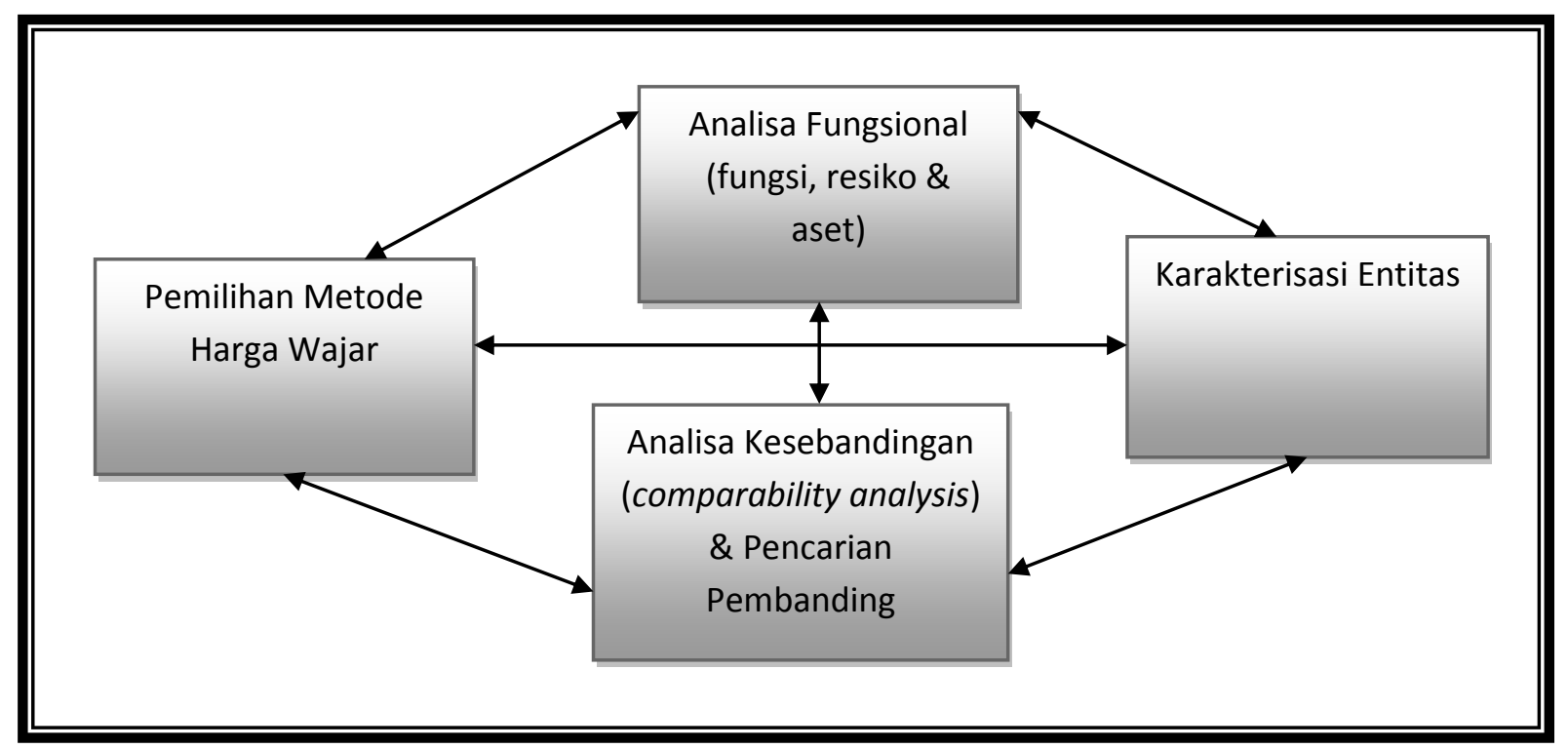

Gambar 4.2

Transfer Pricing Diamond

Sumber: Special Reports "Transfer Pricing and Characterization of Multinational Enterprise Operations with a Focus on Canada and the U.S”, hlm 755. Diolah kembali oleh penulis

Sementara itu, dalam Penjelasan Pasal 18 ayat 4 Huruf b mengenai konsep hubungan istimewa yang timbul karena adanya penguasaan langsung maupun tidak langsung. Hubungan istimewa di antara wajib pajak dapat juga terjadi karena penguasaan melalui manajemen atau penggunaan teknologi walaupun tidak terdapat hubungan kepemilikan. Hubungan istimewa dianggap ada apabila satu atau lebih perusahaan berada
Dalam hal terdapat hubungan keluarga, yang dimaksud dengan "hubungan keluarga sedarah dalam garis keturunan lurus satu derajat" adalah ayah, ibu, dan anak, sedangkan "hubungan keluarga sedarah dalam garis keturunan ke samping satu derajat" adalah saudara. Sementara, yang dimaksud dengan "keluarga semenda dalam garis keturunan lurus satu derajat” adalah mertua dan anak tiri, sedangkan "hubungan keluarga semenda 
dalam garis keturunan ke samping satu derajat" adalah ipar.

Di Indonesia, melalui Peraturan Direktur Jenderal Pajak Nomor Per32/PJ/2011 Tentang Penerapan Prinsip Kewajaran dan Kelaziman Usaha Dalam Transaksi Antara Wajib Pajak Dengan Pihak yang Mempunyai Hubungan Istimewa Pasal 3 Ayat 4 dijelaskan bahwa pihak yang dikecualikan untuk melakukan penerapan arm's length principle adalah pihak-pihak yang mempunyai hubungan istimewa dengan nilai seluruh transaksi tidak melebihi $\mathrm{Rp}$ 10.000.000.000,00 (sepuluh milyar rupiah) dalam satu tahun pajak untuk setiap lawan transaksi.

Selanjutnya, dalam hal wajib pajak diwajibkan untuk menerapkan arm's length principle, Pasal 3 Ayat 2 Peraturan Direktur Jenderal Pajak Nomor Per-32/PJ/2011 Tentang Penerapan Prinsip Kewajaran dan Kelaziman Usaha Dalam Transaksi Antara Wajib Pajak Dengan Pihak yang Mempunyai Hubungan Istimewa telah mengatur mengenai langkah - langkah yang harus dilakukan dalam menerapkan arm's length principle, yaitu:

1. Melakukan analisis kesebandingan dan menentukan pembanding;

2. menentukan metode penentuan harga transfer yang tepat;

3. menerapkan Prinsip Kewajaran dan Kelaziman Usaha berdasarkan hasil Analisis Kesebandingan dan metode

4. Penentuan Harga Transfer yang tepat ke dalam transaksi yang dilakukan antara Wajib Pajak dengan pihak yang mempunyai Hubungan Istimewa ; dan
5. mendokumentasikan setiap langkah dalam menentukan Harga Wajar atau Laba Wajar sesuai dengan ketentuan perundang-undangan perpajakan yang berlaku.

Sementara itu, Hendrik Swanveld, Charles Osro, Martin Przysuski, Srini Lalapet, dan Pallavi Paul dalam Special Reports yang berjudul "Transfer Pricing and Characterization of Multinational Enterprise Operations with a Focus on Canada and the U.S" memperkenalkan skema Transfer Pricing Diamond sebagai langkah - langkah dalam menerapkan arm's length principle.

\subsubsection{Karakterisasi Entitas}

Berdasarkan special reports tersebut, langkah pertama yang harus diterapkan dalam proses pemenuhan arm's length principle diantara ketiga langkah lainnya yang tertera dalam skema di atas adalah karakterisasi entitas (characterization of entities), sementara untuk langkah berikutnya dapat dipilih diantara ketiga langkah lainnya tanpa adanya keutamaan atau skala prioritas. Proses karakterisasi entitas bersifat vital sehingga proses ini ditempatkan ke dalam langkah pertama yang harus dilakukan dalam proses pemenuhan arm's length principle.

Karakterisasi entitas yang dimaksud dalam hal ini adalah penentuan dan analisa bahwa entitas - entitas atau perusahaan - perusahaan yang sedang dianalisa benar - benar merupakan associated enterprise atau dikategorikan memiliki hubungan istimewa, dengan mempertimbangkan konsep hubungan istimewa sebagaimana yang dijelaskan 
sebelumnya. Selain itu dalam proses karakterisasi entitas, juga dilakukan analisa mengenai bisnis atau operasional kegiatan usaha yang dilakukan oleh entitas yanng dianalisa, mencakup lingkup operasi bisnis hingga kondisi keuangan entitas tersebut.

4.1.2 Analisis Kesebandingan (Comparability Analysis)

Comparability analysis memegang peranan yang penting dalam proses pemenuhan arm's length principle. Comparability analysis dalam cakupan arm's length principle menitikberatkan tingkat kesebandingan antara pihak yang berada dalam lingkup hubungan istimewa (controlled transactions) dengan pihak yang bersifat independen (uncontrolled transactions). Peranan penting comparability analysis tercermin dalam paragraf 1.6 OECD TP Guidelines yang menyatakan bahwa "comparability analysis is at the heart of the application of the arm's length principle".

Direktorat Jenderal Pajak melalui Peraturan Direktur Jenderal Pajak Nomor Per-32/PJ/2011 Tentang Penerapan Prinsip Kewajaran dan Kelaziman Usaha Dalam Transaksi Antara Wajib Pajak Dengan Pihak yang Mempunyai Hubungan Istimewa Pasal 1 Ayat 7 mendefinisikan analisis kesebandingan sebagai analisis yang dilakukan oleh wajib pajak atau Direktorat Jenderal Pajak atas kondisi dalam transaksi yang dilakukan antara wajib pajak dengan pihak yang mempunyai hubungan istimewa, dan melakukan identifikasi atas perbedaan kondisi dalam kedua jenis transaksi dimaksud. Surat Direktur Pemeriksaan dan Penagihan Nomor
S-153/PJ.04/2010 Tentang Panduan Pemeriksaan Kewajaran Transaksi Afiliasi Lampiran 1 Huruf C Nomor 4 menjelaskan tujuan melakukan analisis kesebandingan adalah untuk (i) mengidentifikasi perbedaan kondisi transaksi dengan kondisi transaksi independen yang menjadi pembanding, yang memberi pengaruh terhadap hasil transaksi dan (ii) menyimpulkan karakter dari kondisi transaksi yang diperbandingkan.

Di dalam Pasal 4 Peraturan Direktur Jenderal Pajak Nomor Per-32/PJ/2011 Tentang Penerapan Prinsip Kewajaran dan Kelaziman Usaha Dalam Transaksi Antara Wajib Pajak Dengan Pihak yang Mempunyai Hubungan Istimewa, dikatakan bahwa transaksi yang dilakukan antara Wajib Pajak dengan pihak yang mempunyai hubungan istimewa dianggap sebanding dengan transaksi yang dilakukan antara pihak-pihak yang tidak mempunyai Hubungan Istimewa dalam hal :

1. tidak terdapat perbedaan kondisi yang material atau signifikan yang dapat mempengaruhi harga atau laba dari transaksi yang diperbandingkan; atau

2. terdapat perbedaan kondisi, namun dapat dilakukan penyesuaian untuk menghilangkan pengaruh yang material atau signifikan dari perbedaan kondisi tersebut terhadap harga atau laba;

Hal ini sejalan dengan ketentuan yang termuat dalam paragraf 1.33 OECD TP Guidelines yang menyatakan bahwa: to be comparable means that none differences (if any) 
between the situations being compared could materially affect the condition being examined in the methodology (e.g price or margin), or that reasonably accurate adjustments that can be made to eliminate the effect of any such differences. Pernyataan dalam paragraf tersebut mensyaratkan bahwa tingkat kesebandingan dalam upaya pemenuhan arm's length principle dianggap telah tercapai apabila tidak terdapat lagi perbedaan hal - hal yang bersifat material antara pihak yang saling berafiliasi dengan pihak yang bersifat independen. Apabila perbedaan tersebut masih ada, maka dalam memenuhi ketentuan arm's length principle, diperlukan suatu adjustment yang memungkinkan untuk dilakukan guna mengeliminasi adanya perbedaan yang bersifat material tersebut, sehingga tercapailah derajat kesebandingan yang tinggi.

Dalam melakukan analisa kesebandingan antara controlled transactions dan uncontrolled transactions, Peraturan Direktur Jenderal Pajak Nomor PER32/PJ/2011 Tentang Penerapan Prinsip Kewajaran Dan Kelaziman Usaha dan OECD TP Guidelines memberikan panduan mengenai 5 (lima) faktor yang harus dianalisa dalam menetukan tingkat comparability. Kelima faktor tersebut adalah:

1. Karakterisasi Barang Atau Jasa Karakterisasi barang atau jasa dalam hal ini dapat berupa bentuk fisik barang yang terlibat dalam proses transaksi, mencakup spesifikasi kualitas produk dan jumlah volume produk. Sedangkan dalam hal konteks transaksi transfer jasa, analisa kesebandingan dapat dilakukan terhdap jenis jasa dan contractual terms terkait jasa yang diberikan.

2. Analisis Fungsional (Functional Analysis/FAR Analysis)

OECD TP Guidelines dalam paragraf 1.42 mengemukakan bahwa functional analysis adalah faktor yang sangat penting yang harus diperhatikan dalam melakukan analisis kesebandingan. Analisis fungsional akan membantu memahami struktur dan organisasi grup perusahaan serta pengaruhnya terhadap kegiatan usaha, sekaligus membantu memahami hak dan kewajiban wajib pajak dalam melaksanakan fungsi operasi bisnisnya. Secara lebih proporsional, Surat Direktur Pemeriksaan dan Penagihan Nomor S153/PJ.04/2010 Tentang Panduan Pemeriksaan Kewajaran Transaksi Afiliasi Lampiran 1 Huruf C Nomor 5 menjelaskan bahwa tujuan analisis fungsional adalah untuk (i) mengidentifikasi perbedaan substansi usaha para pihak yang terlibat dalam transaksi yang diperbandingkan, baik dalam transaksi afiliasi maupun transaksi independen, yang memberi pengaruh terhadap hasil transaksi dan (ii) menyimpulkan karakter dari para pihak yang terlibat dalam transaksi sebagai dasar untuk menyimpulkan substansi usaha para pihak tersebut.

Dalam Peraturan Direktur Jenderal Pajak Nomor PER-32/PJ/2011 Tentang Penerapan Prinsip Kewajaran Dan Kelaziman Usaha Pasal 7 ayat 3 , dijelaskan mengenai hal - hal yang yang harus dipertimbangkan dalam melakukan analisa fungsional, yaitu sebagai berikut: 
1) Struktur organisasi dan posisi perusahaan yang diuji dalam kelompok usaha serta manajemen mata rantai (supply chain management) kelompok usaha;

2) Fungsi-fungsi utama yang dijalankan oleh suatu perusahaan seperti desain, pengolahan, perakitan,penelitian,pengem bangan, pelayanan, pembelian, distribusi, pemasaran, promosi,transportasi,keuangan, dan manajemen seperti jasa perantara (toll manufacturing), manufaktur dengan fungsi dan risiko terbatas (contract manufacturing), dan manufaktur dengan fungsi dan risiko penuh (fully fledge manufacturing);

3) Jenis aktiva yang digunakan atau akan digunakan seperti tanah, bangunan, peralatan, dan Harta Tidak Berwujud, serta sifat dari aktiva tersebut seperti umur, harga pasar, dan lokasi;

4) Resiko yang mungkin timbul dan harus ditanggung oleh masing-masing pihak yang melakukan transaksi seperti risiko pasar, risiko kerugian investasi, dan risiko keuangan.

\section{Contractual Terms}

Dalam konteks pemenuhan arm's length principle, contractual terms baik secara eksplisit dan implisit diartikan sebagai bentuk pertanggungjawaban, resiko, dan keuntungan (benefits) yang dibagi diantara pihak - pihak yang saling berafiliasi. Hal ini sejalan dengan ketentuan dalam Peraturan Direktur Jenderal Pajak Nomor PER-32/PJ/2011 Tentang Penerapan Prinsip Kewajaran Dan Kelaziman
Usaha Pasal 8 yang menyatakan bahwa dalam melakukan penilaian dan analisis atas ketentuan-ketentuan dalam kontrak / perjanjian, harus dilakukan analisis terhadap tingkat tanggung jawab, risiko, dan keuntungan yang dibagi antara pihak-pihak yang mempunyai hubungan istimewa untuk dibandingkan dengan ketentuan-ketentuan dalam kontrak/perjanjian yang dilakukan oleh pihak-pihak yang tidak mempunyai hubungan istimewa, yang meliputi ketentuan tertulis dan tidak tertulis. Sedangkan, dalam hal tidak terdapat dokumen tertulis, hubungan kontrak para pihak dapat ditentukan dari peran/perilaku para pihak atau prinsip ekonomi, yang umumnya mengatur hubungan para pihak tersebut. Beberapa ketentuan yang harus diperhatikan dalam menganalisa ketentuan dalam kontrak antara lain adalah cara pembayaran dan jangka waktu pembayaran, volume penjualan dan/atau pembelian, serta jaminan yang diberikan.

\section{Keadaan Ekonomi (Economic circumstances) \\ Dalam Peraturan Direktur Jenderal} Pajak Nomor PER-32/PJ/2011 Tentang Penerapan Prinsip Kewajaran Dan Kelaziman Usaha Pasal 9, dijelaskan bahwa analisis keadaan ekonomi diperlukan untuk memperoleh tingkat kesebandingan dalam pasar tempat beroperasinya para pihak yang melakukan transaksi. Dalam pasal tersebut di atas juga dijelaskan mengenai cakupan keadaan ekonomi yang harus diidentifikasi 
dalam proses analisa kesebandingan, hal tersebut mencakup:

1) Lokasi geografis;

2) ukuran pasar;

3) tingkat persaingan dalam pasar serta posisi persaingan antara penjual dan pembeli;

4) ketersediaan barang atau jasa pengganti;

5) tingkat permintaan dan penawaran dalam pasar baik secara keseluruhan maupun regional;

6) daya beli konsumen;

7) sifat dan cakupan peraturan pemerintah dalam pasar;

8) biaya produksi termasuk biaya tanah, upah tenaga kerja, dan modal; biaya transportasi; dan tingkatan pasar;

9) tanggal dan waktu transaksi; dan sebagainya.

\section{Strategi Bisnis (Business strategy)}

Strategi bisnis dalam konteks analisa kesebandingan, menurut OECD TP Guidelines mencakup inovasi dan pengembangan produk baru, derajat diversifikasi, hingga penetrasi dan ekspansi market. Analisa terhadap strategi bisnis diperlukan sebab startegi bisnis yang dijalankan oleh perusahaan dapat memberikan pengaruh yang signifikan terhadap profit yang diperoleh oleh perusahaan yang bersangkutan. a. Penentuan Pembanding, Langkah selanjutnya yang harus diperhatikan dalam menerapkan arm's length principle adalah menentukan transaksi atau pihak pembanding yang independen, yang akan digunakan sebagai pembanding dengan transaksi yang dilakukan oleh pihak yang memiliki hubungan istimewa.

Di dalam Surat Direktur Pemeriksaan dan Penagihan Nomor S-153/PJ.04/2010 Tentang Panduan Pemeriksaan Kewajaran Transaksi Afiliasi Lampiran 1 Huruf A Nomor 9, pembanding didefinisikan sebagai transaksi independen sebanding yang digunakan sebagai acuan dalam menetukan kewajaran harga dan keberadaan transaksi antar pihak yang memiliki hubungan istimewa.Pembanding yang digunakan dalam menganalisa transaksi hubungan istimewa dibedakan atas pembanding internal dan pembanding eksternal.

b. Pemilihan Metode Harga Wajar/Harga Transfer, Pemilihan metode harga wajar dalam rangka memenuhi arm's length principle diatur di dalam Peraturan Direktur Jenderal Pajak Nomor Per-32/PJ/2011 Tentang Penerapan Prinsip Kewajaran dan Kelaziman Usaha Dalam Transaksi Antara Wajib Pajak Dengan Pihak yang Mempunyai Hubungan Istimewa. Di dalam pasal 11 datur bahwa dalam penentuan metode harga wajar atau laba wajar wajib dilakukan kajian untuk menentukan metode penentuan harga transfer yang paling sesuai (The Most Appropiate Method).

Untuk menghitung dan menentukan harga transfer yang wajar diantara pihak yang memiliki hubungan istimewa/berafiliasi, terdapat lima metode yang diakui baik secara nasional (dalam Peraturan Direktur Jenderal Pajak Nomor Per - 32/PJ/2011) maupun 
internasional (berdasarkan OECD TP Guidelines), yang dikelompokkan menjadi dua jenis, yaitu:

1. Metode Tradisional, terdiri atas:

- Metode Perbandingan Harga Antara Pihak yang Tidak Mempunyai Hubungan Istimewa (Comparable Uncontrolled Price Method/CUP Method)

- Metode Harga Penjualan Kembali (Resale Price Method/RPM)

- Metode Biaya-Plus (Cost Plus Method/CPM)

2. Metode Transactional Profit, terdiri atas:

- Metode Pembagian Laba (Profit split Method/PSM)

- Metode laba Bersih Transaksional (Transactional Net Margin Method/TNMM)

Berikut adalah penjelasan mengenai metode harga wajar:

1) Metode Perbandingan Harga Antara Pihak yang Tidak Mempunyai Hubungan Istimewa (Comparable Uncontrolled Price Method/CUP Method) CUP Method merupakan metode penentuan harga transfer yang dilakukan dengan membandingkan harga dalam transaksi yang dilakukan antara pihak-pihak yang mempunyai hubungan istimewa dengan harga barang atau jasa dalam transaksi yang dilakukan antara pihak-pihak yang tidak mempunyai hubungan istimewa dalam kondisi atau keadaan yang sebanding.

2) Metode Harga Penjualan Kembali (Resale Price Method/RPM)

Merupakan metode penentuan harga transfer yang dilakukan dengan membandingkan harga dalam transaksi suatu produk yang dilakukan antara pihak-pihak yang mempunyai hubungan istimewa dengan harga jual kembali produk tersebut setelah dikurangi laba kotor wajar, yang mencerminkan fungsi, aset dan risiko, atas penjualan kembali produk tersebut kepada pihak lain yang tidak mempunyai hubungan istimewa atau penjualan kembali produk yang dilakukan dalam kondisi wajar. Kondisi yang tepat dalam menerapkan metode ini antara lain adalah:

- tingkat kesebandingan yang tinggi antara transaksi antara wajib pajak yang mempunyai hubungan istimewa dengan transaksi antara wajib pajak yang tidak mempunyai hubungan istimewa, khususnya tingkat kesebandingan berdasarkan hasil analisis fungsi, meskipun barang atau jasa yang diperjualbelikan berbeda; dan

- pihak penjual kembali (reseller) tidak memberikan nilai tambah yang signifikan atas barang atau jasa yang diperjualbelikan 
3) Metode Biaya-Plus (Cost Plus Method/CPM)

Merupakan metode yang dilakukan dengan menambahkan tingkat laba kotor wajar yang diperoleh perusahaan yang sama dari transaksi dengan pihak yang tidak mempunya hubungan istimewa atau tingkat laba kotor wajar yang diperoleh perusahaan lain dari transaksi sebanding dengan pihak yang tidak mempunyai hubungan istimewa pada harga pokok penjualan yang telah sesuai dengan prinsip kewajaran dan kelaziman usaha. Kondisi yang tepat dalam menerapkan metode ini antara lain adalah:

- barang setengah jadi dijual kepada pihak-pihak yang mempunyai Hubungan Istimewa;

- terdapat kontrak/perjanjian penggunaan fasilitas bersama (joint facility agreement) atau kontrak jualbeli jangka panjang (long term buy and supply agreement) antara pihakpihak yang mempunyai Hubungan Istimewa; atau bentuk transaksi adalah penyediaan jasa.

4) Metode Pembagian Laba (Profit split Method/PSM)

Merupakan metode penentuan harga transfer berbasis laba transaksional (transactional profit method based) yang dilakukan dengan mengidentifikasi laba gabungan atas transaksi afiliasi yang akan dibagi oleh pihak-pihak yang mempunyai hubungan istimewa tersebut dengan menggunakan dasar yang dapat diterima secara ekonomi yang memberikan perkiraan pembagian laba yang selayaknya akan terjadi dan akan tersermin dari kesepakatan antar pihak-pihak yang tidak mempunyai hubungan istimewa, dengan menggunakan metode kontribusi (contribution profit split method) atau metode sisa pembagian laba (residual profit spilt method). Kondisi yang tepat dalam menerapkan metode ini antara lain adalah:

- transaksi antara pihak-pihak yang mempunyai hubungan istimewa sangat terkait satu sama lain sehingga tidak dimungkinkan untuk dilakukan kajian secara terpisah; atau

- terdapat barang tidak berwujud yang unik antara pihak-pihak yang bertransaksi yang menyebabkan kesulitan dalam menemukan data pembanding yang tepat.

5) Metode laba Bersih Transaksional (Transactional Net Margin Method/TNMM)

TNMM merupakan metode yang dilakukan dengan membandingkan presentase laba bersih operasi terhadap biaya, terhadap penjualan, terhadap aktiva, atau terhadap dasar lainnya atas transaksi antara pihakpihak yang mempunyai hubungan istimewa dengan persentase laba bersih operasi yang diperoleh atas transaksi sebanding dengan pihak lain yang tidak mempunya hubungan istimewa atau persentase laba bersih operasi yang diperoleh atas transaksi sebanding yang dilakukan oleh pihak yang tidak mempunyai hubungan isitimewa lainnya. Kondisi yang 
tepat dalam menerapkan metode ini antara lain adalah:

- salah satu pihak dalam transaksi hubungan istimewa melakukan kontribusi yang khusus; atau

- salah satu pihak dalam transaksi Hubungan Istimewa melakukan transaksi yang kompleks dan memiliki transaksi yang berhubungan satu sama lain.

Secara lebih lanjut, di dalam Pasal 11 Ayat 8 Peraturan Direktur Jenderal Pajak Nomor Per-32/PJ/2011 Tentang Penerapan Prinsip Kewajaran dan Kelaziman Usaha Dalam Transaksi Antara Wajib Pajak Dengan Pihak yang Mempunyai Hubungan Istimewa dijelaskan pula mengenai hal-hal yang harus diperhatikan dalam memilih metode penetuan harga transfer yang paling sesuai. Hal-hal tersebut terdiri atas:

1) kelebihan dan kekurangan setiap metode;

2) kesesuaian metode penentuan harga transfer dengan sifat dasar transaksi antar pihak yang mempunyai hubungan istimewa, yang ditentukan berdasarkan analisis fungsional;

3) ketersediaan informasi yang handal (sehubungan dengan transaksi antar pihak yang tidak mempunyai hubungan istimewa) untuk menerapkan metode yang dipilih dan/atau metode lain;

4) tingkat kesebandingan antara transaksi antar pihak yang mempunyai hubungan istimewa dengan transaksi antar pihak yang tidak mempunyai hubungan istimewa, termasuk kehandalan penyesuaian yang dilakukan untuk menghilangkan pengaruh yang material dari perbedaan yang ada.

6) Kewajiban Dokumentasi Transaksi Hubungan Istimewa

Berkaitan dengan transaksi hubungan istimewa yng dilakukan oleh wajib pajak, Peraturan Direktur Jenderal Pajak Nomor Per-32/PJ/2011 Tentang Penerapan Prinsip Kewajaran dan Kelaziman Usaha Dalam Transaksi Antara Wajib Pajak Dengan Pihak yang Mempunyai Hubungan Istimewa Pasal 18 telah mengatur mengenai kewajiban pendokumentasian atas transaksi hubungan istimewa tersebut. Wajib pajak yang melakukan transaksi dengan pihak yang mempunyai hubungan istimewa wajib untuk menyelenggarakan dan menyimpan dokumen yang menjadi dasar penerapan prinsip kewajaran dan kelaziman usaha atas transaksi yang dilakukannya tersebut. Dokumen tersebut terdiri atas satu set dokumen induk dan satu set lampiran dari dokumen induk.

Dalam hal pendokumentasian tersebut, wajib pajak diperkenankan untuk menentukan sendiri jenis dan bentuk dokumen yang disesuaikan dengan bidang usahanya sepanjang dokumen tersebut mendukung penggunaan metode penentuan harga wajar atau laba wajar yang dipilih, termasuk laporan keuangan yang tersegmentasi. Dokumen penentuan Harga Wajar atau Laba Wajar yang harus disediakan oleh Wajib Pajak sekurang-kurangnya mencakup: 
- gambaran perusahaan secara rinci seperti struktur kelompok usaha, struktur kepemilikan, struktur organisasi, aspek-aspek operasional kegiatan usaha, daftar pesaing usaha, dan gambaran lingkungan usaha;

- kebijakan penetapan harga dan/atau penetapan alokasi biaya;

- hasil Analisis Kesebandingan atas karakteristik produk yang diperjualbelikan, hasil analisis fungsional, kondisi ekonomi, ketentuan-ketentuan dalam kontrak/perjanjian, dan strategi usaha.

- $\quad$ pembanding yang terpilih;

- catatan mengenai penerapan metode penentuan Harga Wajar atau Laba Wajar yang dipilih oleh Wajib Pajak serta alasan penolakan metode yang tidak dipilih.

7) Koreksi Terhadap Penghasilan Kena Pajak Pada Transaksi Hubungan Istimewa

Pemerintah Indonesia, dalam hal ini melalu Direktur Jenderal Pajak, memiliki kewenangan untuk menentukan kembali besarnya penghasilan dan/atau biaya dalam transaksi pihak-pihak yang mempunya hubungan istimewa, sesuai dnegan keadaan seandainya diantara para wajib pajak tersebut tidak terdapat hubungan istimewa. Hal ini diatur dalam Undang-Undang Pajak Penghasilan Nomor 36 Tahun 2008 Pasal 18 Ayat 3. Penentuan kembali besarnya penghasilan dan/atau biaya ini dilakukan apabila terdapat kemungkinan penghasilan dilaporkan kurang dari semstinya ataupun pembebanan biaya melebihi dari yang seharusnya dan dilakukan dengan mempertimbangkan metode dan dokumen penentuan harga wajar atau laba wajar yang diterapkan oleh wajib pajak.

8) Penyelasaian Sengketa yang Timbul Akibat Transaksi Hubungan Istimewa (Sengketa Transfer Pricing)

Sengketa transfer pricing atau sengketa yang timbul karena adanya transaksi yang dilakukan oleh pihak-pihak yang memiliki hubungan istimewa, dapat terjadi baik antara sesama wajib pajak, maupun antara wajib pajak dengan otoritas pajak. Sengketa yang timbul dapat berupa munculnya pemajakan berganda yang disebabkan karena otoritas pajak di masing-masing negara tempat pihakpihak berafiliasi tersebut bertransaksi, menentukan harga pasar wajar yang berbeda atas transaksi yang terjadi. Darussalam dan Danny Septriadi dalam bukunya Konsep dan Aplikasi Cross-Border Transfer Pricing Untuk Tujuan Perpajakan, menyatakan bahwa instrumen yang dapat dilakukan untuk menyelesaikan sengketa transfer pricing dapat meliputi: (i) Mutual Agreement Procedures (MAP); (ii) Advance Pricing Agreement (APA); (iii) Arbitration.

- $\quad$ Mutual Agreement Procedures (MAP) adalah prosedur administratif yang dilakukan oleh pejabat yang berwenang dari Indonesia dengan 
pejabat yang berwenang dari negara mitra

- Advance Pricing Agreement (APA) Pemerintah Indonesia melalui Undang-Undang Pajak Penghasilan Nomor 36 Tahun 2008 dalam Penjelasan Pasal 18 Ayat 3A telah menjelasakan bahwa Kesepakatan harga transfer (Advance Pricing Agreement/APA) adalah kesepakatan antara wajib pajak dan Direktur Jenderal Pajak mengenai harga jual wajar produk yang dihasilkannya kepada pihak-pihak yang mempunyai hubungan istimewa (related parties) dengannya.

\section{- Arbitration (Arbitrase)}

Klausal mengenai arbitrase termuat di dalam Persetujuan Penghindaran Pajak Berganda atau P3B (tax treaty). Kalausal ini dibuat untuk menyelesaikan perselisihan atas sengketa transfer pricing, maupun menyelesaikan perselisihan yang timbul dalam penerapan suatu tax treaty.

9) Kesesuaian pemenuhan prinsip kewajaran dan kelaziman usaha (arm's length principle) atas transkasi pinjaman (loan) oleh lembaga keuangan (Perbankan) kepada perusahaan yang berafiliasi

Berdasarkan pembahasan dan langkah yang telah dijelaskan sebelumnya, maka pihak yang bersangkutan (perusahaan) diwajibkan untuk menerapkan prinsip kewajaran dan kelaziman usaha atau arm's length principle atas transaksinya tersebut dengan menerapkan langkah-langkah analisa yang diatur dalam Peraturan Direktur Jenderal Pajak Nomor Per - 32/PJ/2011 Tentang Penerapan Prinsip Kewajaran Dan Kelaziman Usaha Dalam Transaksi Antara Wajib Pajak Dengan Pihak yang Mempunyai Hubungan Istimewa dalam rangka meng-analisis tingkat kewajaran atas transaksi yang dilakukan pihak yang bersangkutan (perusahaan) dengan afiliasinya.

\section{PENUTUP}

\section{Simpulan}

Proses pemenuhan prinsip kewajaran dan kelaziman usaha (arm's length principle) atas transkasi pinjaman (loan) oleh lembaga keuangan (Perbankan) kepada perusahaan yang berafiliasi. Karakterisasi Entitas menjadi alas an dari pemilihan metode Analisis Kesebandingan (Comparability Analysis). Dalam kondisi tertentu Karakterisasi Barang Atau Jasa sangat menentukan hasil Analisis Fungsional (Functional Analysis/FAR Analysis) sehingga diperlukan waktu yang bersifat contractual dalam mensiasati keadaan ekonomi

\section{Saran}

Strategi Bisnis (Business strategy) menjadi penentuan pembanding dalam rangka kompetisi usaha secara fair. Penentuan Pembanding bisa dilakukan dengan memilih metode dengan harga Wajar/Harga Transfer yang selayaknya berlaku. Kewajiban 
dokumentasi dibutuhkan apabila pihak pihak yang berafliasi membangun relasi istimewa sehingga koreksi terhadap pajak, serta sengketa dalam hubungan transfer pricing, bisa diselesaikan Penyelasaian Sengketa yang Timbul Akibat Transaksi Hubungan Istimewa (Sengketa Transfer Pricing). Kesesuaian pemenuhan prinsip kewajaran dan kelaziman usaha (arm's length principle) atas transkasi pinjaman (loan) oleh lembaga keuangan (Perbankan) kepada perusahaan yang berafiliasi.

\section{Ucapan Terima Kasih}

Ucapan terima kasih penulis ucapkan kepada Universitas Indonesia yang telah membiayai penelitian ini dengan skema Hibah Riset Awal DRPM UI

\section{DAFTAR PUSTAKA}

Anselm Strauss \& Juliet Corbin, Dasar-dasar Penelitian Kualitatif : Tata Langkah dan Teknik-teknik Teoritisasi Data, terjemahan Muhammad Shodiq \& Imam Muttaqien, Pustaka Pelajar, Yogyakarta, 2003, hal 5

Creswell, John W., Research Design-Qualitative, Quantitative Approaches, New Delhi : Sage Publication, 1984. Hal 164

Darussalam dan Septriadi, Konsep dan Aplikasi Cross-Border Tranfer Pricing untuk Tujuan Perpajakan, Danny darussalam tax Center, Jakarta, 2008.

Gunadi, Akuntansi dan Pemeriksaan Pajak, Cetakan Pertama Abdi Tandur, Jakarta, 1999.

Haemakers Hubert, Arm’s length-How long?”, International Tranfer Pricing Journal, 2001.

Husein Umar, Metode Riset Ilmu Administrasi. Ilmu Administrasi Negara, Pembangunan, dan Niaga, Jakarta : Gramedia Pustaka Utama. 2004. hal. 2

Irawan, Prasetya,"Logika dan Prosedur Penelitian, pengantar Teori dan Panduan Praktik Penelitian Sosial Bagi mahasiswa dan Peneliti Pemula", Jakarta : STIA LAN Press, 2004 hal 61.

Neuman W laurence, Socail Research Methods, Qualitative and Quantitative Approaches, United States of America : Allyn and Bacon, Inc., 1999. Hal 31.

Sudarwan Danim, Pengantar Studi Penelitian Kebijakan, Bumi Aksara, Jakarta, 2000, hal 187

Sensi, Ludovicus W, Memahami lebih Jauh Aspek Earnings Management, Financial Shenanigans dan Rekayasa Keuangan, Economics Business and Accounting Review, Volume II Nomor 1 Januari April 2007.

W. Lawrence Nauman, Social Research Methods: Qualitative and Quantitatives approach, Fifth Edition, Allyn and Bacon, Boston, 2003, hal 448-449

\section{Sumber lainnya:}

UU No 10 Tahun 1998 tentang Perbankan (direvisi melalui Keppres RI No 16 Tahun 2004) 